\title{
Sekizinci Sınıf Öğrencilerinin Geometri Problemi Kurma Becerileri ile Geometri Öz-Yeterlik İnançları Arasındaki İlişkinin İncelenmesi*
}

\section{Investigation of the Relationship between Eighth Grade Students' Geometry Problem Posing Skills and Their Geometry Self-Efficacy Beliefs}

\author{
Mehmet Ertürk GEÇİCí $\dot{~}^{* *}$ (iD) Mehmet AYDIN ${ }^{* * *}$ (iD)
}

Received: 31 August 2018

Research Article

Accepted: 10 December 2018

\begin{abstract}
The aim of this research is to investigate the relationship between eighth grade students' geometry problem posing skills and their self-efficacy beliefs towards geometry in different problem posing situations. In addition, the students' geometry problem posing skills have been investigated in terms of gender, parental education status, general academic success and mathematics course success. The sample of the study conducted by the survey model was composed of 151 students who were in the eighth grade. The "Geometry Problem Posing Test" developed by the researchers and the "Self-Efficacy Scale Toward Geometry" developed by Cantürk-Günhan and Başer (2007) were used as data collection tools. Data obtained from the study were analyzed with SPSS 22.0 program. As a result of the analysis of data, it was found that the scores of the students' geometry problem posing test did not show any significant difference according to the gender but they showed a significant difference according to the educational status of the parents. It was also determined that students' geometry problem posing test scores showed a significant difference according to both general academic achievement and mathematics achievement. Moreover, it was found that there is a moderate correlation and significant relationship between geometry problem posing skills of students and their self-efficacy beliefs towards geometry.
\end{abstract}

Keywords: self-efficacy beliefs towards geometry, geometry problem posing skill, mathematics education.

ÖZ: $\mathrm{Bu}$ araştırmanın amacı, sekizinci sınıf öğrencilerinin farklı problem kurma durumlarında geometri problemi kurma becerileri ile geometriye yönelik öz-yeterlik inançları arasındaki ilişkiyi incelemektir. Bunun yanında öğrencilerin geometri problemi kurma becerileri cinsiyet, anne-baba eğitim durumu, genel akademik başarı ve matematik dersi başarısı açısından araştırılmıştır. Tarama modeli ile yürütülen çalışmanın örneklemini sekizinci sınıfta öğrenim görmekte olan 151 öğrenci oluşturmuştur. Araştırmacılar tarafından geliştirilen "Geometri Problemi Kurma Testi" ve Cantürk-Günhan ve Başer (2007) tarafından geliştirilen "Geometriye Yönelik Öz-Yeterlik Ölçeği” veri toplama araçları olarak kullanılmıştır. Araştırmada elde edilen veriler SPSS 22.0 programı ile analiz edilmiştir. Verilerin analizi sonucunda öğrencilerin geometri problemi kurma testi puanlarının cinsiyete göre anlamlı farklılık göstermediği ancak anne-baba eğitim durumlarına göre anlamlı bir farklılık gösterdiği bulunmuştur. Öğrencilerin geometri problemi kurma testi puanlarının hem genel akademik başarılarına göre hem de matematik dersindeki başarılarına göre anlamlı bir farklılık gösterdiği de belirlenmiştir. Ayrıca öğrencilerin geometri problemi kurma becerileri ile geometriye yönelik öz-yeterlik inançları arasında orta düzeyde ve anlamlı bir ilişki olduğu bulunmuştur.

Anahtar kelimeler: geometriye yönelik öz-yeterlik inançları, geometri problemi kurma becerisi, matematik eğitimi.

*This study is part of master thesis entitled "An Investigation of Eighth Grade Students' Skills at Geometry Problem Posing" by first author conducted in supervisor of second author. Also, this study was presented as an oral presentation at the $3^{\text {rd }}$ INES International Education and Social Science Congress.

**Corresponding Author: Res. Assist., Afyon Kocatepe University, Afyonkarahisar, Turkey,erturkgecici@gmail.com, https://orcid.org/0000-0002-5250-1419

***Asst. Prof. Dr., Dicle University, Diyarbakır, Turkey, mehmet.aydin@dicle.edu.tr, https://orcid.org/0000-0002$0718-8662$

Citation Information

Geçici, M. E., \& Aydın, M. (2019). Sekizinci sınıf öğrencilerinin geometri problemi kurma becerileri ile geometri özyeterlik inançları arasındaki ilişkinin incelenmesi. Kuramsal Eğitimbilim Dergisi [Journal of Theoretical Educational Science], 12(2), 431-456. 


\section{Giriş}

Günümüz eğitim anlayışında matematik öğretiminin amaçlarından biri, bireyin karşılaştığı sorunları problem çözme yaklaşımı çerçevesinde değerlendiren bir düşünce şekli kazandırmaktır (Altun, 2014). Ortaokul matematik öğretim programında da problem çözme becerilerinin üzerinde önemle durulması gerektiğinden ve problem çözmenin matematik dersinin ayrılmaz bir parçası olduğundan bahsedilmektedir (Milli Eğitim Bakanlığı [MEB], 2009, 2013, 2018). Problem çözme yoluyla öğrenciler matematiğin faydasını ve gücünü tecrübe edebilecekleri için problem çözme matematik müfredatı ile iç içe olmalıdır (National Council of Teachers of Mathematics [NCTM], 2000). Baki (2008), matematik eğitiminde öğrencilere gerekli becerileri kazandırmanın problem çözme yoluyla sağlanabileceğini vurgulamaktadır. Matematik eğitimi açısından önemli görülen problem çözme süreci Polya’ya (1973) göre dört temel aşamadan oluşur. Bu aşamalar:

$>$ Problemi anlama,

$>$ Problemi uygun şekilde çözmek için plan yapma,

$>$ Planı uygulayarak çözüme ulaşma,

$>$ Çözümü değerlendirmedir.

Gonzales (1994), Polya'nın problem çözme sürecinde ifade ettiği bu 4 adıma yeni bir adım eklemiş ve beşinci adım olarak çözülen probleme benzer bir problem kurma adımından bahsetmiştir. Problem kurma, verilen bir durumun keşfedilmesi için yeni problemlerin üretilmesi veya mevcut bir problemin tekrardan biçimlendirilmesi anlamına gelmektedir (Silver, 1994). Stoyanova (1997) ise; problem kurmay1 öğrencilerin matematiksel deneyimlerine dayanarak, somut durumlardan kişisel yorumlarını oluşturdukları ve bunları anlamlı yapılandırılmış matematik problemleri olarak biçimlendirdikleri süreç olarak tanımlamıştır.

Öğrenciler bir problemi farklı yollarla yorumladıkları durumlarda, farklı cevaplar bulabileceklerinden, zengin ve yararlı tartışmalar gerçekleşebilir. $\mathrm{Bu}$ sebeple sadece problemi çözmek değil, problemi kurmak, problemleri sınıflandırmak ve problemleri çözmenin farklı yollarını bulmak da önemli etkinliklerdir (Walter, 1980). Olkun ve Toluk-Uçar (2014), problem çözmenin başkalarının belirlediği problemleri çözmenin dışında problemi fark etme, problemin sınırlarını ve özelliklerini belirleme, problemi tanıma ve problemi kurma gibi ön aşamaları da içerdiğini belirtmişlerdir. $\mathrm{Bu}$ bağlamda problem çözmenin yanı sıra problem kurmanın da matematik öğretiminde öneme sahip olduğu söylenebilir.

Problem kurma, matematiksel düşünmeyi ve özellikle öğrencilerin problem çözme becerilerini geliştirmeye yardımcı olabilecek yararlı bir sınıf etkinliği olarak görülmektedir (Cifarelli \& Sevim, 2015). Kilpatrick (1987), kişinin kendi matematik problemlerini keşfetme ve yaratma deneyiminin her öğrencinin eğitiminin bir parçası olması gerektiğinden bahsetmiştir. Çünkü öğrenciler, kendi problemlerini kurmaya teşvik edildiklerinde kendi öğrenmelerinde yeni ve daha aktif bir rol alırlar (Brown \& Walter, 2005).

Singer, Ellerton ve Cai (2015) problem kurmanın okul matematiğinin önemli bir parçası olduğunu belirtmişlerdir. Problem kurmanın önemli görülmesinden dolayı bu alanda son yıllarda birçok çalışma yapılmıştır (Arıkan \& Unal, 2015; Bonotto, 2013; Çelik \& Yetkin-Özdemir; 2011; Kar, 2016; Kılıç, 2013; Silber \& Cai, 2017; Singer ve 
diğerleri, 2015; Singer, Voica, \& Pelczer, 2017). Arıkan ve Ünal (2015) sekizinci sınıf öğrencilerinin dört işlem, kesirler ve geometrik ölçümler ile ilgili kurdukları problemleri incelemişlerdir. Cai (1998), Amerikalı ve Çinli altıncı sınıf öğrencilerinin dört işlem ve örüntü konularında problem çözme ve problem kurma etkinliklerini karşılaştırma yaparak incelemiştir. Çelik ve Yetkin-Özdemir (2011), ortaokul öğrencilerinin oranorantı konusunda kurdukları problemleri incelemişlerdir. Çalışmada öğrencilerin orantısal akıl yürütme becerileriyle problem kurma becerilerinin arasındaki ilişki araştırılmıştır. Problem kurma ile ilgili yapılan çalışmalar örnekleme ya da çalışılan konuya göre farklılık göstermektedir.

Ortaokul öğrencileri ile yürütülen bu problem kurma çalışmalarında sayılar ve işlemler ya da cebir öğrenme alanları ile ilgili birçok çalışma (Akkan, Çakıroğlu, \& Güven, 2009; Bonotto, 2013; Bunar, 2011; Cai, 1998; Stoyanova, 2005; Turhan \& Güven, 2014) yapılmasına karşın geometri öğrenme alanı ile ilgili yapılan çalışmaların eksikliği dikkat çekmektedir. Bununla ilgili Chua ve Wong (2012), problem kurma konusundaki çalışmaların çoğunun aritmetik kelime problemleri ile ilgili olduğundan geometri problemi kurma konusundaki bilgi birikiminin sınırlı kaldığını belirtmişlerdir. Problem kurmanın matematik eğitiminde önemli olduğunu belirten görüşler çerçevesinde, öğrencilerin geometriye yönelik kuracakları problemlerin incelenmesi de araştırılması gereken bir konu olarak düşünülmektedir.

Ünlü (2014), anaokulundan üniversiteye kadar geçen süreçte, öğrencilerin geometri ile ilgili kavramları öğrenmesi ve günlük hayatta uygulayabilmesi için, öğrencilere uygun öğrenme ortamlarının sunulması gerektiğini belirtmektedir. Nitekim öğretim programlarında da bu amaca yönelik olarak birçok kazanım bulunmaktadır. 2009 öğretim programında geometrik kavramlarla ilgili problem çözmenin yanı sıra problem kurma ile ilgili kazanımların olması da dikkat çekmiştir. Bu kazanımlara birkaç örnek aşağıda sunulmuştur (MEB, 2009):

$>$ "Dörtgensel bölgelerin alanları ile ilgili problemleri çözer ve kurar."

$>$ "Dikdörtgenler prizması, kare prizma ve küpün hacmi ile ilgili problemleri çözer ve kurar."

$>$ "Dairenin ve daire diliminin alanı ile ilgili problemleri çözer ve kurar."

> "Geometrik cisimlerin yüzey alanları ile ilgili problemleri çözer ve kurar."

Sonraki öğretim programlarında (MEB, 2013, 2018) yukarıdakilere benzer kazanımların eksikliği dikkat çekmiştir. Öğrencilerin geometri problemlerini çözme ve kurma becerilerinin geliştirilmesi adına bu kazanımların katkısının olabileceği düşünülmektedir. Bununla ilgili olarak Walter (1980), problem kurma ve çözme sayesinde öğrencilerin geometriyi, bir grup tanım olarak bilmek, şekilleri tanımak ve sınıflandırmaktan daha fazlası olduğunu göreceklerini belirtmiştir. Şengül-Akdemir ve Türnüklü (2017) yaptıkları literatür taraması sonucunda problem kurma ile ilgili geometri alanında eksiklik olduğunu vurgulamışlardır ve açılar konusuna yönelik bir çalışma yapmışlardır. Geometride problem kurma ile ilgili başka çalışmalar olduğu da görülmüştür (Chua \& Wong, 2012; Lavy \& Bershadsky, 2003; Singer ve diğerleri, 2017; Türnüklü, Ergin, \& Aydoğdu, 2017). Ancak ortaokul öğrencilerine yönelik geometri problemi kurma çalışmaları sınırlılık göstermektedir.

$\mathrm{Bu}$ çalışmada Stoyanova ve Ellerton'1n (1996) sunduğu serbest, yar1yapılandırılmış ve yapılandırılmış problem kurma durumlarına yönelik bir araştırma yapılmıştır. Literatürde farklı problem kurma durumlarını birlikte inceleyen çalışmalar 
sınırlılık göstermektedir (Çarkçı, 2016; Kılıç, 2013; Kırnap-Dönmez, 2014; Ngah, Ismail, Tasir, \& Said, 2016; Özgen, Aydın, Geçici, \& Bayram, 2017). Söz konusu nedenlerle öğrencilerin farklı problem kurma durumlarında kurdukları geometri problemleri incelenmiştir.

Çalışmada geometri problemi kurma becerileri ile ilişkisi araştırılan değişkenlerden biri öğrencilerin geometriye ilişkin öz-yeterlik inançlarıdır. Zimmerman (1995) öz-yeterliği, "Kişinin bir işi yapabilme, başarabilme yeteneği konusundaki yargıları" şeklinde tanımlamıştır. Bıkmaz (2014), insanların hedeflerini gerçekleştirmeye çalışırken bu bireysel yargılarını kullandıklarını ifade etmiştir. Özgen ve Bindak (2011), öz-yeterlik inancının eğitim alanında farklı disiplinlerin öğrenme süreçlerinde önemli bir kavram olarak görüldüğünü vurgulamıştır. Öz-yeterlik inançlarının eğitim üzerine etkileri incelendiğinde, bilgi ve eylem arasındaki ilişkiye aracılık ettiği için motivasyon ve davranış üzerinde önemli etkileri bulunduğu görülür (Pajares, 1996). Öz-yeterlik inançlarının öğrenme üzerinde bir takım etkilerinin olduğu görülmektedir. $\mathrm{Bu}$ durumda, matematiğin bir dalı olan geometride de öz-yeterlik inançlarının etkilerinin olması beklenmektedir.

Kaba, Boğazliyan ve Daymaz (2016), geometriye yönelik öz-yeterliği, "Bireyin geometri etkinliklerini organize edip bu etkinlikleri başarılı olarak yapma kapasitesi, geometriyi başarabilme yeteneği konusundaki yargıları ve kendine güveni” şeklinde tanımlamışlardır. Ünlü ve Ertekin (2017) ise "Bireyin doğrudan deneyimler ya da dolaylı yaşantılar yoluyla edindiği, geometriye yönelik bir problem veya etkinliğin üstesinden gelmesine ilişkin kendi bilgi, beceri ve kapasitesine ilişkin yargısıdır." şeklinde tanımlamışlardır. Literatürde öz-yeterlik ile problem kurma arasındaki ilişkileri araştıran bazı çalışmalar olduğu görülmektedir (Akay \& Boz, 2010; Nicolaou \& Philippou, 2007). Akay ve Boz (2010) çalışmalarında, problem kurmanın öğretmen adaylarının matematik öz-yeterliği ve matematiğe yönelik tutumları üzerinde anlamlı düzeyde olumlu bir etkisi olduğunu belirlemişlerdir.

Literatürde öğretmenlerin (Kılıç \& İncikabı, 2013) ve ortaokul öğrencilerinin (Özgen \& Bayram, 2018) problem kurma konusunda öz-yeterlik inançlarını ölçme amacıyla ölçeklerin geliştirildiği de görülmüştür. Bununla ilgili öğretmen (Altıntaş \& Tanrıseven, 2017) ve öğretmen adaylarının (Deringöl, 2018; Ünlü \& Aktaş, 2016) problem kurma ile ilgili öz-yeterlik inançlarını inceleyen araştırmalar bulunmaktadır. Altıntaş ve Tanrıseven (2017), sınıf öğretmenlerinin problem kurmaya yönelik özyeterlik inançlarının yüksek olduğunu belirlemişlerdir. Aynı sonuca Deringöl (2018), sınıf öğretmeni adayları ile; Ünlü ve Aktaş (2016) ise, matematik öğretmeni adayları ile ulaşmışlardır. Ancak ortaokul öğrencilerinin problem kurma becerileri ile öz-yeterlik inançları arasındaki ilişkiyi araştıran çalışma bulunmamaktadır. Bu sebeple, ortaokul öğrencilerinin geometri problemi kurma becerilerinin geometri öz-yeterlik inançları açısından incelenmesinin gerekli olduğu düşünülmüştür. $\mathrm{Bu}$ noktadan hareketle araştırmanın amacı, farklı problem kurma durumlarında sekizinci sınıf öğrencilerinin geometri problemi kurma becerileri ile geometriye yönelik öz-yeterlik inançları arasındaki ilişkiyi incelemektir. Bunun yanında öğrencilerin geometri problemi kurma becerileri cinsiyet, başarı, anne-baba eğitim durumu gibi başka değişkenlere göre de araştırılmıştır. Bu doğrultuda araştırmanın alt problemleri aşağıdaki gibi belirlenmiştir:

1. Sekizinci sınıf öğrencilerinin geometri problemi kurma becerileri, öğrencilerin cinsiyetlerine, anne-baba eğitim durumlarına, genel akademik 
başarılarına ve matematik dersi başarılarına göre anlamlı bir farklılık göstermekte midir?

2. Sekizinci sınıf öğrencilerinin geometriye yönelik öz-yeterlik inançları, geometri problemi kurma becerilerinin anlamlı bir yordayıcısı mıdır?

\section{Yöntem}

Araştırma, tarama modelinde tasarlanan nicel bir çalışmadır. Tarama modeli, bir evren içinden seçilen bir örneklemin eğilimlerinin, tutumlarının veya fikirlerinin niceliksel olarak betimlenmesini sağlar (Creswell, 2014).

\section{Araştırma Grubu}

Araştırma, Şanlıurfa ili Haliliye ilçesinde bulunan bir devlet okulunda gerçekleştirilmiştir. Araştırma grubunu sekizinci sınıfta öğrenim görmekte olan 151 öğrenci oluşturmuştur. Katılımcılar basit seçkisiz örnekleme yolu ile seçilmiştir. Araştırma grubunu oluşturan öğrencilerin cinsiyetlerine göre dağılımları Tablo 1'de gösterilmiştir.

Tablo 1

Öğrencilerin Cinsiyete Göre Dă̆llımları

\begin{tabular}{lcc}
\hline Cinsiyet & $n$ & $\%$ \\
\hline Kiz & 80 & 53.0 \\
Erkek & 71 & 47.0 \\
Toplam & 151 & 100 \\
\hline
\end{tabular}

Araştırma grubu, $80 \mathrm{kız}$ ve 71 erkek öğrenciden oluşmaktadır. Katılımcıların cinsiyetleri bakımından birbirlerine yakın sayıda olduğu söylenebilir. Ancak, araştırmanın örnekleminde yer alan kız öğrenciler erkek öğrencilerden biraz daha fazla sayıdadır. Araştırma grubunu oluşturan öğrencilerin başarılarına göre dağılımları Tablo 2 'de gösterilmiştir. Başarı durumları sınıflandırılırken öğrencilerin 1. dönem elde ettikleri karne notları dikkate alınmıştır.

Tablo 2

Öğrencilerin Başarılarına Göre Dă̆glımları

\begin{tabular}{lcccc}
\hline Başarı Düzeyi & \multicolumn{2}{c}{ Matematik Başarısı } & \multicolumn{2}{c}{ Genel Akademik Başarı } \\
& $n$ & $\%$ & $n$ & $\%$ \\
\hline A-Zayıf (0-44) & 8 & 5.3 & 2 & 4.3 \\
B-Geçer (45-54) & 19 & 12.6 & 7 & 17.2 \\
C-Orta (55-69) & 25 & 16.5 & 26 & 25.8 \\
D-İyi (70-84) & 35 & 23.2 & 39 & 51.0 \\
E-Çok İyi (85-100) & 64 & 42.4 & 77 & 100 \\
Toplam & 151 & 100 & 151 & \\
\hline
\end{tabular}


Tablo 2 incelendiğinde çalışmaya katılan öğrencilerin başarılarının puan olarak 85-100 arasında yoğunlaştığı görülmektedir. Çalışmanın yapıldığı okul Şanlıurfa İli dikkate alındığında sosyo-ekonomik yönden gelişmiş olan bir okuldur. Çalışma yapılan okulun her yıl birçok öğrencisi başarılı liselere yerleşebilmektedir. Ayrıca çalışılan okulun mezunları önceki yıllarda temel eğitimden ortaögretime geçiş ortak sınavlarında ilçede başarılı sonuçlar almıştır. Ortak sınavlardaki okul ortalamaları ile Türkiye ortalamaları karşılaştırıldığında ise çalışılan okulun Türkiye ortalaması ile yakın ortalamalara sahip olduğu görülmüş̧ür.

Araştırma grubunu oluşturan öğrencilerin anne-baba eğitim durumlarına göre dağılımları Tablo 3 'te gösterilmiştir.

Tablo 3

Ö̆rrencilerin Anne-Baba Ĕ̆itim Durumlarına Göre Dă̆llımları

\begin{tabular}{lcccc}
\hline Eğitim Düzeyi & \multicolumn{2}{c}{ Anne Eğitim Durumu } & \multicolumn{2}{c}{ Baba Eğitim Durumu } \\
& $n$ & $\%$ & $n$ & $\%$ \\
\hline A-Okur-yazar değil & 11 & 7.3 & 2 & 1.3 \\
B-İlkokul & 36 & 23.9 & 16 & 13.2 \\
C-Ortaokul & 35 & 23.2 & 20 & 38.4 \\
D-Lise & 44 & 29.1 & 58 & 25.2 \\
E-Lisans & 15 & 9.9 & 38 & 11.3 \\
F-Lisansüstü & 10 & 6.6 & 17 & 100 \\
Toplam & 151 & 100 & 151 & \\
\hline
\end{tabular}

Öğrencilerin anne-baba eğitim durumlarına bakıldığında, her ikisi için de lise seviyesinin ağırlıklı olduğu görülmüştür. Ancak baba eğitim durumu lisans ve lisansüstü düzeylerde artış gösterirken, anne eğitim durumu ortaokul ve ilkokul seviyesinde artış göstermiştir. $\mathrm{Bu}$ durumun sebebi olarak okulun yer aldiğı ilin bulunduğu bölge düşünüldüğünde kadınların eğitim düzeylerinin genel olarak erkeklerin gerisinde olduğu söylenebilir.

\section{Veri Toplama Araçları}

Araştırmada; "Geometri Problemi Kurma Testi", "Geometriye Yönelik ÖzYeterlik Ölçeği”, ve "Kişisel Bilgi Formu” kullanılarak veriler toplanmıştır. Kişisel Bilgi Formu; öğrencilerin cinsiyetlerini, matematik dersindeki başarılarını, genel akademik başarılarını ve anne-baba eğitim durumlarını belirlemeye yönelik sorulardan oluşmaktadır.

Öğrencilere ait karne başarı puanları 5 kategoriye ayrılmıştır. Bunlar sırasıyla; "0-44 arası A-Zayıf, 45-54 arası B-Geçer, 55-69 arası C-Orta, 70-84 arası D-İyi ve 85100 arası E-Çok iyi” şeklindedir. Öğrencilerin anne-baba eğitim durumları ise 6 kategoride ele alınmıştır. Bu kategoriler sırasıyla; "A-Okur-yazar değil, B-İlkokul, COrtaokul, D-Lise, E-Lisans, F-Lisansüstü” şeklindedir. 
“Geometri Problemi Kurma Testi”, sekizinci sınıf öğretim programında geometri ve ölçme öğrenme alanında yer alan üçgenler ve eşlik-benzerlik alt öğrenme alanlarına yönelik olarak (bkz. Ek-1) hazırlanmıştır. Testin üçgenler ve eşlik-benzerlik alt öğrenme alanlarını ölçecek şekilde olmasının sebebi ise üçgenler alt öğrenme alanının sekizinci sınıf öğretim programında geniş yer tutmasıdır. Ayrıca üçgenlerin geometri öğrenme alanında önem taşıyan bir konu olduğu ifade edilmektedir (Türnüklü ve diğerleri, 2017). 6 açık uçlu problem kurma etkinliğinden oluşan testte serbest problem kurma durumları için Pisagor bağıntısı ve eşlik-benzerlik kavramlarını içeren problem kurma etkinlikleri bulunmaktadır. Yarı-yapılandırılmış problem kurma durumları için açı-kenar ilişkisi ve üçgen eşitsizliği bağlamı içeren problemler sorulmuştur. Yapılandırılmış problem kurma durumları için ise, temel benzerlik teoremi ve üçgenin yardımcı elemanlarını içeren problemler bulunmaktadır.

Testin geçerlik ve güvenirliğini sağlamak amacıyla, alanında uzman iki alan eğitimi uzmanından görüş alınmıştır. Uzman görüşleri doğrultusunda soruların dil, seviye, içerik ve kapsam geçerliği sağlanmıştır. Testin güvenirliğini sağlamak için "puanlayıcılar arası uyum" yöntemi uygulanmıştır. Biri araştırmacı diğeri ise matematik öğretmeni olan iki farklı puanlayıcı öğrencilerin kurdukları problemleri değerlendirmişlerdir.

Öğrencilerin geometri öz-yeterliklerini belirlemek amacıyla Cantürk-Günhan ve Başer'in (2007) geliştirdiği “Geometriye Yönelik Öz-Yeterlik Ölçeği” kullanılmıştır. Ortaokul öğrencilerine yönelik olan ölçekte 25 madde bulunmaktadır. Ölçek, olumlu özyeterlik inançları, geometri bilgisinin kullanılması ve olumsuz öz-yeterlik inançları olmak üzere 3 alt boyuttan oluşmaktadır. 5'li Likert tipinde olan ölçek, "Hiçbir zaman (1), ara sıra (2), kararsızım (3), çoğu zaman (4), her zaman (5)" şeklinde derecelendirilmiştir. Ölçekte yer alan olumsuz maddeler analiz öncesinde tersten kodlanmıştır. Ölçeğe ait Cronbach's alpfa güvenirlik katsayıları ile bu araştırmadaki ölçeğin ölçüm güvenirlik katsayıları Tablo 4'te verilmiştir.

Tablo 4

Ölçeğin Alt Boyutlart ve Cronbach's Alpha Güvenirlik Katsayıları

\begin{tabular}{lccc}
\hline Alt Boyut & Madde Sayıları & $\begin{array}{c}\text { Cronbach's } \\
\text { Alpha }\end{array}$ & $\begin{array}{c}\text { Çalısmadaki Cronbach's } \\
\text { Alpha }\end{array}$ \\
\hline Olumlu Öz-yeterlik İnançları & 12 & .88 & .87 \\
Geometri Bilgisinin Kullanılması & 6 & .70 & .68 \\
Olumsuz Öz-yeterlik İnançları & 7 & .70 & .72 \\
Genel & 25 & .90 & .90
\end{tabular}

Tablo 4 incelendiğinde, ölçeğe ait Cronbach's Alpha katsayılarının .70 ile .88 arasında olduğu görülmektedir. Benzer şekilde, çalışmadaki Cronbach's Alpha katsayıları .68 ile .87 arasında olduğu bulunmuştur. Ölçeğin genel Cronbach's Alpha katsayısı ise, hem orijinal çalışmada hem de bu çalışmada .90 olarak bulunmuştur. Buradan, çalışmadan elde edilen verilerin iç tutarlılığın yüksek olduğu söylenebilir. 


\section{Verilerin Analizi}

Öğrenciler tarafından kurulan problemler, Özgen ve diğerleri (2017) tarafından geliştirilen derecelendirilmiş puanlama anahtarı (rubrik) ile değerlendirilmiştir. Bu rubriğin ortaokul öğrencilerine yönelik olması ve matematik problemlerini farklı özellikleri bakımından değerlendirdiğinden dolayı kullanılması uygun bulunmuştur. Puanlama anahtarı, öğrencilerin problem kurma becerilerini değerlendirme kriterleri olarak yedi farklı kriter içermektedir. Bu kriterler; "Matematik dilini (sembol, gösterim) kullanma, dil bilgisi ve ifade uygunluğu, kurulan problemin kazanımlara uygunluğu, problemdeki veri miktarı ve niteliği, kurulan problemin çözülebilirliği, problemin özgünlüğü ve öğrenci tarafından çözülme durumu" şeklindedir. Puanlama anahtarında yer alan her bir kritere ait dört farklı düzey bulunmaktadır. Bu düzeyler; 1. düzey (0 puan), 2. düzey (1 puan), 3. düzey (2 puan) ve 4 . düzey (3 puan) şeklinde değerlendirilmiştir. Örnek bir değerlendirme Şekil 1'de verilmiştir.

Şekil 1. Örnek Değerlendirme

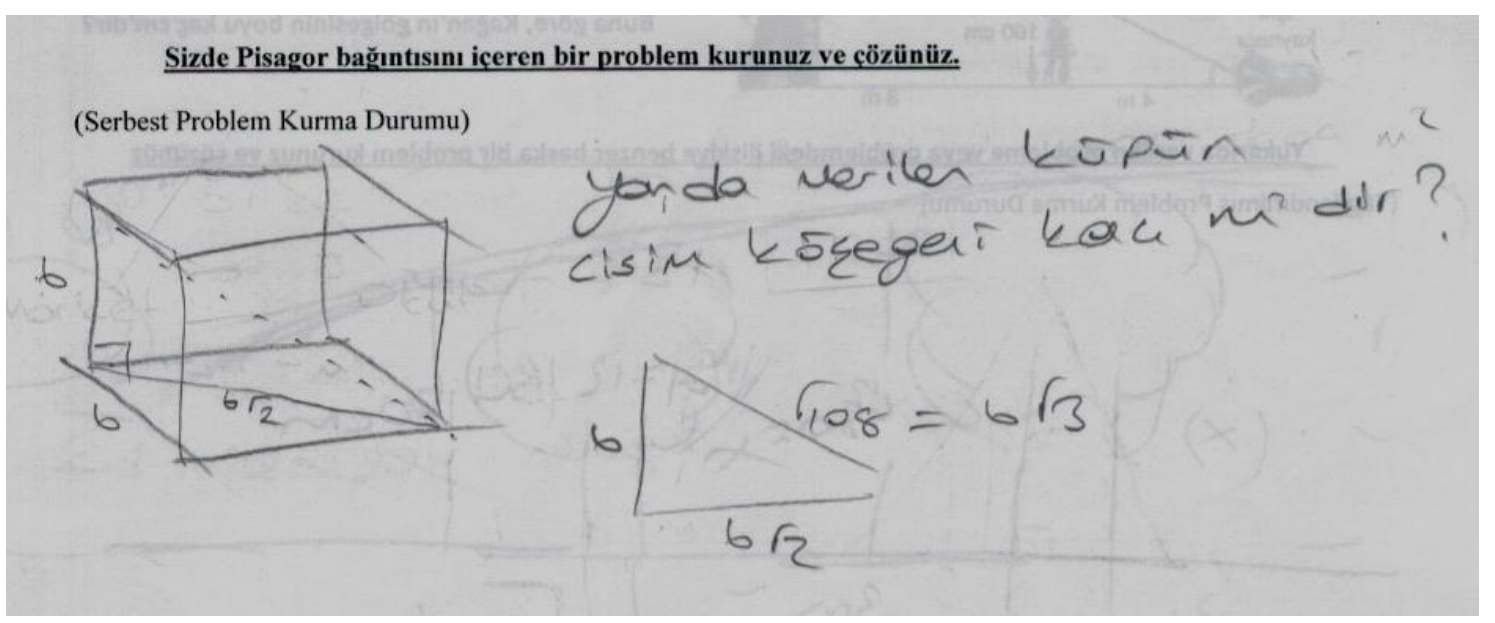

Şekil 1'de öğrencinin Pisagor bağıntısı ile ilgili kurmuş olduğu serbest problem kurma etkinliği sunulmaktadır. Öğrencinin kurduğu problem anlaşılır bir biçimde ifade edilmiştir ve çözülebilir bir problem olduğu görülmektedir. Kurduğu problemin çözümünü de gösteren öğrencinin, problemi oluştururken geometrinin başka bir alt öğrenme alanı olan geometrik cisimler ile problemi ilişkilendirmesi problemin özgünlüğünü göstermektedir. Öğrencinin bu cevabı 4. düzey olarak değerlendirilmiştir.

Öğrencilerin yanıtları puanlama anahtarına göre biri matematik öğretmeni diğeri araştırmacı iki kişi tarafından birbirinden bağımsız bir biçimde puanlanmıştır. Sonrasında, Miles ve Huberman'ın (1994) önerdiği “[(Görüş Birliği) / (Görüş Birliği) + (Görüş Ayrılığı)] x 100" güvenirlik yüzdesi hesaplanmıştır. Bu formüle göre puanlayıcılar arası uyum \%78 bulunmuştur. Uyum yüzdesinin birbirine yakınlığı, yapılan puanlamanın tutarlı olduğunu göstermektedir. Farklı yapılan puanlamalar da tartışılarak ortak bir karara varılmıştır. Bu şekilde puanlamadaki tutarsızlık ortadan kaldırılmıştır.

Verilerin analizine başlamadan önce, verilerin dağılımlarının normallik sınamasında Kolmogorov-Smirnov testi yapılmış aynı zamanda puanların çarpıklıkbasıklık değerlerine bakılmıştır. Kolmogorov-Smirnov testi sonucuna göre, anlamlılık değerinin .05 'ten büyük çıktığı ve çarpıklık basıklık katsayısının George ve Mallery’e 
(2010) göre +2.0 ile -2.0 arasında olduğu için verilerin normal dağılım gösterdiği görülmüş ve bu nedenle parametrik testler kullanılmıştır. Öğrencilerin geometri problemi kurma testinde aldıkları puanların cinsiyete göre anlamlı farklılık gösterip göstermediğinin belirlenmesinde ilişkisiz örneklemler için t-testi kullanılırken; annebaba eğitim durumları, genel akademik başarı ve matematik dersi başarısı değişkenlerine göre anlamlı bir farklılık gösterip göstermediğinin belirlenmesinde ilişkisiz örneklemler için tek faktörlü ANOVA testi kullanılmıştır. Öğrencilerin geometri öz-yeterlik puanlarının geometri problemi kurma becerilerini yordamasına yönelik basit regresyon analizi uygulanmıştır. Öncesinde ise geometriye yönelik özyeterlik inançları ve geometri problemi kurma becerileri arasında ilişki olup olmadığını belirlemek amacıyla Pearson Momentler Çarpımı Korelasyonu hesaplanmıştır. Araştırmanın yapılan analizler sonucu ulaşılan bulgularına ileriki bölümde yer verilmiştir.

\section{Bulgular}

Sekizinci sınıfta öğrenim gören öğrencilerin geometri problemi kurma becerileri öncelikle cinsiyet değişkeni açısından incelenmiştir. Geometri problemi kurma testinden elde edilen puanların cinsiyet değişkeni bakımından t-testi sonuçları Tablo 5'te sunulmuştur.

Tablo 5

Ögrencilerin Geometri Problemi Kurma Testi Puanlarının Cinsiyete Göre T-Testi Sonuçları

\begin{tabular}{|c|c|c|c|c|c|c|c|}
\hline Durum & Cinsiyet & $n$ & $\bar{x}$ & $S S$ & $S d$ & $t$ & $p$ \\
\hline \multirow[t]{2}{*}{ Serbest } & $\mathrm{K}_{1 \mathrm{Z}}$ & 80 & 21.73 & 12.33 & 149 & -.077 & $.939 *$ \\
\hline & Erkek & 71 & 21.87 & 11.20 & & & \\
\hline \multirow[t]{2}{*}{ Yarı-yapılandırılmış } & $\mathrm{K} 1 \mathrm{z}$ & 80 & 19.28 & 13.34 & 149 & .206 & $.837 *$ \\
\hline & Erkek & 71 & 18.82 & 13.90 & & & \\
\hline \multirow[t]{2}{*}{ Yapılandırılmış } & Kiz & 80 & 16.00 & 12.68 & 149 & -.190 & $.850 *$ \\
\hline & Erkek & 71 & 16.38 & 11.85 & & & \\
\hline \multirow[t]{2}{*}{ Toplam Puan } & $\mathrm{K}_{1 \mathrm{Z}}$ & 80 & 57.00 & 28.72 & 149 & -.016 & $.988^{*}$ \\
\hline & Erkek & 71 & 57.07 & 26.81 & & & \\
\hline
\end{tabular}

$* p>.05$

Tablo 5'e bakıldığında, öğrencilerin geometri problemi kurma testindeki puanlarının cinsiyete göre anlamlı farklılık göstermediği görülmektedir [t(149)=.988, $p>.05]$. Geometri problemi kurma testi puanlarında anlamlı farklılık görülmese de, erkek öğrenciler daha yüksek bir ortalamaya sahiptir. Ayrıca öğrencilerin serbest $[\mathrm{t}(149)=.939, p>.05]$, yarı-yapılandırılmış $[\mathrm{t}(149)=.837, p>.05]$ ve yapılandırılmış $[\mathrm{t}(149)=.850, p>.05]$ problem kurma durumlarındaki puanlarının, cinsiyete göre anlamlı bir farklılık göstermediği bulunmuştur. Bundan yola çıkarak cinsiyet değişkeninin geometri problemi kurmada anlamlı bir fark oluşturmayacağı düşünülmektedir. 
Öğrencilerin geometri problemi kurma becerilerinin anne eğitim durumuna göre anlamlı bir fark oluşturup oluşturmadığı araştırılan bir diğer değişkendir. ANOVA testi sonucu ulaşılan bulgular Tablo 6'da verilmiştir.

Tablo 6

Öğrencilerin Geometri Problemi Kurma Testi Puanlarının Anne Ĕgitim Durumuna Göre ANOVA Sonuçları

\begin{tabular}{|c|c|c|c|c|c|c|c|}
\hline Durum & $\begin{array}{c}\text { Varyansın } \\
\text { Kaynağı }\end{array}$ & Kar. Top. & $S d$ & Kar. Ort. & $F$ & $p$ & $\begin{array}{l}\text { Anlamlı } \\
\text { Fark }\end{array}$ \\
\hline \multirow[t]{3}{*}{ Serbest } & $\begin{array}{c}\text { Gruplar } \\
\text { Arası }\end{array}$ & 850.44 & 5 & 170.08 & 1.235 & .296 & \\
\hline & Gruplar içi & 19964.19 & 145 & 137.68 & & & \\
\hline & Toplam & 20814.63 & 150 & & & & \\
\hline \multirow{3}{*}{$\begin{array}{c}\text { Yarı- } \\
\text { yapılandırılmış }\end{array}$} & $\begin{array}{c}\text { Gruplar } \\
\text { Arası }\end{array}$ & 1594.35 & 5 & 318.87 & 1.778 & .121 & \\
\hline & Gruplar içi & 26010.10 & 145 & 179.38 & & & \\
\hline & Toplam & 27604.46 & 150 & & & & \\
\hline \multirow[t]{3}{*}{ Yapılandırılmış } & $\begin{array}{c}\text { Gruplar } \\
\text { Aras1 }\end{array}$ & 2648.24 & 5 & 529.64 & 3.860 & $.003 *$ & $\begin{array}{l}\text { B-E, C-E, } \\
\text { D-E, E-F }\end{array}$ \\
\hline & Gruplar içi & 19893.93 & 145 & 137.20 & & & \\
\hline & Toplam & 22542.17 & 150 & & & & \\
\hline \multirow[t]{3}{*}{ Toplam Puan } & $\begin{array}{c}\text { Gruplar } \\
\text { Arası }\end{array}$ & 8969.85 & 5 & 1793.97 & 2.441 & $.037 *$ & B-E \\
\hline & Gruplar içi & 106557.00 & 145 & 734.87 & & & \\
\hline & Toplam & 115526.80 & 150 & & & & \\
\hline
\end{tabular}

Öğrencilerin anne eğitim durumları altı grupta ele alınmıştır ve sırasıyla A, B, C, $\mathrm{D}, \mathrm{E}$ ve $\mathrm{F}$ harfleriyle kodlanmıştır. Öğrencilerin geometri problemi kurma testindeki puanlarının anne eğitim durumları açısından anlamlı farklılık gösterdiğine ulaşılmıştır $[\mathrm{F}(5,145)=2.441, p<.05]$. Bunun yanında yapılandırılmış $[\mathrm{F}(5,145)=3.860, p<.05]$ problem kurma durumlarındaki puanlar ile anne eğitim durumları arasında anlamlı bir farklılık olduğu belirlenmiştir. Eğitim durumları arasındaki farkların hangi gruplar arasında olduğunu belirlemek için yapılan Tukey Testi sonuçlarına göre anneleri lisans ve lisansüstü eğitimi görmüş olan öğrencilerin geometri problemi kurma testi puanlarının anneleri ilkokul, ortaokul ve lise eğitimi görmüş olan öğrencilerin geometri problemi kurma testi puanlarından daha yüksek olduğu bulunmuştur. Bunun neticesinde anne eğitim düzeyi yükseldikçe öğrencilerin geometri problemi kurmada daha başarılı olduğu ortaya çıkmaktadır. 
Ancak; öğrencilerin serbest $[\mathrm{F}(5,145)=1.235, p>.05]$ ve yarı-yapılandırılmış $[F(5,145)=1.778, p>.05]$ durumlardaki puanlarıyla anne eğitim durumları arasında herhangi bir farklılık bulunmamaktadır.

Öğrencilerin geometri problemi kurma becerilerinin baba eğitim durumuna göre anlamlı bir fark oluşturup oluşturmadığı da araştırılmıştır. $\mathrm{Bu}$ bağlamda yapılan ANOVA testi sonuçları Tablo 7'de verilmiştir.

Tablo 7

Öğrencilerin Geometri Problemi Kurma Testi Puanlarının Baba Ĕ̆itim Durumuna Göre ANOVA Sonuçları

\begin{tabular}{|c|c|c|c|c|c|c|c|}
\hline Durum & $\begin{array}{c}\text { Varyansın } \\
\text { Kaynağı }\end{array}$ & Kar. Top. & $S d$ & Kar. Ort. & $F$ & $p$ & $\begin{array}{l}\text { Anlamlı } \\
\text { Fark }\end{array}$ \\
\hline \multirow[t]{3}{*}{ Serbest } & $\begin{array}{c}\text { Gruplar } \\
\text { Aras1 }\end{array}$ & 1025.04 & 5 & 205.00 & \multirow[t]{3}{*}{1.502} & \multirow[t]{3}{*}{.193} & \\
\hline & Gruplar içi & 19789.59 & 145 & 136.48 & & & \\
\hline & Toplam & 20814.63 & 150 & & & & \\
\hline \multirow{3}{*}{$\begin{array}{c}\text { Yarı- } \\
\text { yapılandırılmış }\end{array}$} & $\begin{array}{l}\text { Gruplar } \\
\text { Arası }\end{array}$ & 2058.56 & 5 & 411.71 & \multirow[t]{3}{*}{2.337} & \multirow[t]{3}{*}{$.045^{*}$} & \multirow{3}{*}{$\begin{array}{c}\text { A-B, A-D, } \\
\text { A-E, C-E, } \\
\text { E-F }\end{array}$} \\
\hline & Gruplar içi & 25545.90 & 145 & 176.17 & & & \\
\hline & Toplam & 27604.46 & 150 & & & & \\
\hline \multirow{3}{*}{ Yapılandırılmış } & $\begin{array}{c}\text { Gruplar } \\
\text { Aras1 }\end{array}$ & 926.12 & 5 & 185.22 & \multirow[t]{3}{*}{1.242} & \multirow[t]{3}{*}{.292} & \\
\hline & Gruplar içi & 21615.04 & 145 & 149.07 & & & \\
\hline & Toplam & 22542.17 & 150 & & & & \\
\hline \multirow[t]{3}{*}{ Toplam Puan } & $\begin{array}{c}\text { Gruplar } \\
\text { Aras1 }\end{array}$ & 10249.65 & 5 & 2049.93 & \multirow[t]{3}{*}{2.823} & \multirow[t]{3}{*}{$.018^{*}$} & \multirow{3}{*}{$\begin{array}{c}\text { A-B, A-D, } \\
\text { A-E, A-F, } \\
\text { C-E }\end{array}$} \\
\hline & Gruplar içi & 105277.20 & 145 & 726.05 & & & \\
\hline & Toplam & 115526.80 & 150 & & & & \\
\hline
\end{tabular}

Öğrencilerin baba eğitim durumları altı grupta ele alınmıştır ve sırasıyla A, B, C, $\mathrm{D}, \mathrm{E}$ ve $\mathrm{F}$ harfleriyle kodlanmıştır. Öğrencilerin geometri problemi kurma testindeki puanlarının baba eğitim durumları açısından anlamlı farklılık gösterdiğine ulaşılmıştır $[\mathrm{F}(5,145)=2.823, p<.05]$. Bunun yanında, yarı-yapılandırılmış $[\mathrm{F}(5,145)=2.337, p<.05]]$ problem kurma durumlarındaki puanlar ile baba eğitim durumları arasında anlamlı bir farklılık olduğu bulgusu da bulunmuştur. Eğitim durumları arasındaki farkların hangi gruplar arasında olduğunu belirlemek için yapılan Tukey Testi sonuçlarına göre; babaları lise, lisans ve lisansüstü eğitimi görmüş olan öğrencilerin geometri problemi kurma testi puanlarının babaları okur-yazar olmayan öğrencilerin puanlarına göre daha yüksek olduğu belirlenmiştir. Bu bulgu ile baba eğitim düzeyi arttıkça öğrencilerin geometri problemi kurma etkinliklerinde daha başarılı olduğu söylenebilir. 
Ancak; öğrencilerin serbest $[\mathrm{F}(5,145)=1.502, p>.05]$ ve yapılandırılmış $[\mathrm{F}(5,145)=1.242, p>.05]$ durumlardaki puanlarıla baba eğitim durumları arasında herhangi bir farklılık bulunmamaktadır.

Öğrencilerin geometri problemi kurma becerilerinin genel akademik başarılarına göre anlamlı bir fark gösterip göstermediğini belirlemek için ilişkisiz örneklemler için tek faktörlü ANOVA testi yapılmıştır. Analiz sonuçları Tablo 8'de belirtilmiştir.

Tablo 8

Öğrencilerin Geometri Problemi Kurma Testi Puanlarının Genel Akademik Başarılarına Göre ANOVA Sonuçları

\begin{tabular}{|c|c|c|c|c|c|c|c|}
\hline Durum & $\begin{array}{c}\text { Varyansın } \\
\text { Kaynağı }\end{array}$ & Kar. Top. & $S d$ & Kar. Ort. & $F$ & $p$ & $\begin{array}{l}\text { Anlamlı } \\
\text { Fark }\end{array}$ \\
\hline \multirow{3}{*}{ Serbest } & $\begin{array}{l}\text { Gruplar } \\
\text { Aras1 }\end{array}$ & 3038.60 & 4 & 759.65 & \multirow[t]{3}{*}{6.239} & \multirow[t]{3}{*}{$.000 *$} & \multirow[t]{3}{*}{$\begin{array}{c}\text { B-E, C-D, } \\
\text { C-E }\end{array}$} \\
\hline & Gruplar içi & 17776.03 & 146 & 121.75 & & & \\
\hline & Toplam & 20814.63 & 150 & & & & \\
\hline \multirow{3}{*}{$\begin{array}{c}\text { Yarı- } \\
\text { yapıllandırılmış }\end{array}$} & $\begin{array}{l}\text { Gruplar } \\
\text { Aras1 }\end{array}$ & 5354.01 & 4 & 1338.50 & \multirow[t]{3}{*}{8.783} & \multirow[t]{3}{*}{$.000 *$} & \multirow[t]{3}{*}{$\begin{array}{c}\text { B-E, C-E, } \\
\text { D-E }\end{array}$} \\
\hline & Gruplar içi & 22250.45 & 146 & 152.40 & & & \\
\hline & Toplam & 27604.46 & 150 & & & & \\
\hline \multirow[t]{3}{*}{ Yapılandırılmış } & $\begin{array}{c}\text { Gruplar } \\
\text { Arası }\end{array}$ & 4047.22 & 4 & 1011.80 & \multirow[t]{3}{*}{7.987} & \multirow[t]{3}{*}{$.000 *$} & \multirow[t]{3}{*}{$\begin{array}{l}\text { B-D, B-E, } \\
\text { C-D, C-E }\end{array}$} \\
\hline & Gruplar içi & 18494.94 & 146 & 126.67 & & & \\
\hline & Toplam & 22542.17 & 150 & & & & \\
\hline \multirow[t]{3}{*}{ Toplam Puan } & $\begin{array}{l}\text { Gruplar } \\
\text { Aras1 }\end{array}$ & 35051.73 & 4 & 8762.93 & \multirow[t]{3}{*}{15.898} & \multirow[t]{3}{*}{$.000 *$} & \multirow{3}{*}{$\begin{array}{c}\text { A-E, B-D, } \\
\text { B-E, C-D, } \\
\quad \text { C-E }\end{array}$} \\
\hline & Gruplar içi & 80475.09 & 146 & 551.19 & & & \\
\hline & Toplam & 115526.80 & 150 & & & & \\
\hline
\end{tabular}

$*_{p}<.05$

Öğrencilerin genel akademik başarı puanları; zayıf, geçer, orta, iyi ve çok iyi olmak üzere beş grupta ele alınmıştır ve sırasıyla A,B,C,D ve E harfleri ile kodlanmıştır. Öğrencilerin geometri problemi kurma testindeki toplam puanlarının genel akademik başarılarına göre anlamlı düzeyde farkl1lık gösterdiği bulunmuştur $[\mathrm{F}(4,146)=15.898$, $p<0.5]$. Ayrıca öğrencilerin serbest $[\mathrm{F}(4,146)=6.239, p<0.5]$, yarı-yapılandırılmış $[\mathrm{F}(4,146)=8.783, p<0.5]$ ve yapılandırılmış $[\mathrm{F}(4,146)=7.987, p<0.5]$ problem kurma durumlarındaki puanları genel akademik başarılarına göre anlamlı düzeyde farklılık göstermektedir. Başarı düzeyleri arası anlamlı farkların hangi gruplar arasında olduğunu bulmak amacıyla Tukey Testi yapılmıştır. Test sonuçlarına göre genel akademik başarısı yüksek olan öğrencilerin problem kurma etkinliklerinde elde ettiği puanların, diğer öğrencilerin elde ettiği puanlara göre daha yüksek olduğu bulunmuştur. Bu bulgu 
ile genel akademik başarının problem kurma becerileri ile ilişkili olduğu ve akademik başarısı yüksek öğrencilerin geometri problemi kurma etkinliklerinde daha başarılı olduğu söylenebilir.

Öğrencilerin geometri problemi kurma becerilerinin matematik dersindeki başarılarına göre anlamlı bir fark gösterip göstermediğini belirlemek için ilişkisiz örneklemler için tek faktörlü ANOVA testi yapılmıştır. Analiz sonuçları Tablo 9' da belirtilmiştir.

Tablo 9

Öğrencilerin Geometri Problemi Kurma Testi Puanlarının Matematik Dersi Başarılarına Göre ANOVA Sonuçları

\begin{tabular}{|c|c|c|c|c|c|c|c|}
\hline Durum & $\begin{array}{l}\text { Varyansın } \\
\text { Kaynağ1 }\end{array}$ & Kar. Top. & $S d$ & Kar. Ort. & $F$ & $p$ & $\begin{array}{l}\text { Anlamlı } \\
\text { Fark }\end{array}$ \\
\hline \multirow[t]{3}{*}{ Serbest } & $\begin{array}{c}\text { Gruplar } \\
\text { Arası }\end{array}$ & 3391.28 & 4 & 847.82 & 7.104 & $.000 *$ & \multirow{3}{*}{$\begin{array}{c}\text { A-D, A-E, } \\
\text { B-D, B-E, } \\
\text { C-E }\end{array}$} \\
\hline & Gruplar içi & 17423.35 & 146 & 119.33 & & & \\
\hline & Toplam & 20814.63 & 150 & & & & \\
\hline \multirow{3}{*}{$\begin{array}{c}\text { Yarı- } \\
\text { yapılandırılmış }\end{array}$} & $\begin{array}{c}\text { Gruplar } \\
\text { Arası }\end{array}$ & 7152.39 & 4 & 1788.09 & 12.765 & $.000 *$ & \multirow[t]{3}{*}{$\begin{array}{l}\text { A-E, B-E, } \\
\text { C-E, D-E }\end{array}$} \\
\hline & Gruplar içi & 20452.06 & 146 & 140.08 & & & \\
\hline & Toplam & 27604.46 & 150 & & & & \\
\hline \multirow[t]{3}{*}{ Yapılandırılmış } & $\begin{array}{c}\text { Gruplar } \\
\text { Arası }\end{array}$ & 4184.53 & 4 & 1046.13 & 8.320 & $.000 *$ & \multirow[t]{3}{*}{$\begin{array}{l}\text { A-C, A-D, } \\
\text { A-E, B-E }\end{array}$} \\
\hline & Gruplar içi & 18357.63 & 146 & 125.73 & & & \\
\hline & Toplam & 22542.17 & 150 & & & & \\
\hline \multirow[t]{3}{*}{ Toplam Puan } & $\begin{array}{c}\text { Gruplar } \\
\text { Arası }\end{array}$ & 39809.84 & 4 & 9952.46 & 19.191 & $.000 *$ & \multirow{3}{*}{$\begin{array}{c}\text { A-C, A-D, } \\
\text { A-E, B-D, } \\
\text { B-E, C-E, } \\
\quad \text { D-E }\end{array}$} \\
\hline & Gruplar içi & 75716.98 & 146 & 518.61 & & & \\
\hline & Toplam & 115526.80 & 150 & & & & \\
\hline
\end{tabular}

$* p<.05$

Öğrencilerin matematik dersi başarı puanları; zayıf, geçer, orta, iyi ve çok iyi olmak üzere beş grupta ele alınmıştır ve sırasıyla A,B,C,D ve E harfleri ile kodlanmıştır. Öğrencilerin geometri problemi kurma testi toplam puanlarının matematik dersindeki başarılarına göre anlamlı bir farklılık gösterdiği bulunmuştur $[\mathrm{F}(4,146)=19.191, p<0.5]$. Ayrıca öğrencilerin serbest $[\mathrm{F}(4,146)=7.104, \quad p<0.5], \quad$ yarı-yapılandırılmış $[\mathrm{F}(4,146)=12.765, p<0.5]$ ve yapılandırılmış $[\mathrm{F}(4,146)=8.320, p<0.5]$ problem kurma durumlarındaki puanları ile matematik dersi başarıları arasında anlamlı bir farklılık olduğu bulgusu ortaya çıkmıştır. Başarı düzeyleri arası anlamlı farkların hangi gruplar arasında olduğunu bulmak amacıyla yapılan Tukey Testi sonuçlarına göre matematik dersi başarısı yüksek olan öğrencilerin problem kurma etkinliklerinde elde ettiği 
puanların, diğer öğrencilerin elde ettiği puanlara göre daha yüksek olduğu bulunmuştur. $\mathrm{Bu}$ bulgu ile matematik başarısı yüksek öğrencilerin geometri problemi kurma etkinliklerinde daha başarılı olduğu ortaya çıkmaktadır. Buradan hareketle öğrencilerin matematik dersi başarısının problem kurma becerileri ile ilişkili olduğu söylenebilir.

Geometriye yönelik öz-yeterlik inançları ölçeğinden elde edilen puanların geometri problemi kurma becerilerinin anlamlı bir yordayıcısı olup olmadığını görmek amacıyla basit regresyon analizi yapılmıştır. Regresyon analizi yapılmadan önce geometriye yönelik öz-yeterlik inançları ve geometri problemi kurma becerileri arasındaki ilişkiyi belirlemek amacıyla Pearson Momentler Çarpımı Korelasyonu hesaplanmıştır. Korelasyon analizi sonucunda öğrencilerin geometriye yönelik özyeterlik inançları ile geometri problemi kurma becerileri arasında pozitif yönde ve istatistiksel olarak anlamlı bir ilişki olduğu tespit edilmiştir. Bu tespitin ardından basit regresyon analizi yapılmıştır. Regresyon analizi sonucunda elde edilen bulgular Tablo 10 'da sunulmuştur.

Tablo 10

Öğrencilerin Geometriye Yönelik Öz-Yeterlik Puanlarının Geometri Problemi Kurma Becerilerini Yordamasına Yönelik Basit Regresyon Analizi Sonuçları

\begin{tabular}{|c|c|c|c|c|c|c|c|}
\hline Değişken & $B$ & $\mathrm{SH}_{B}$ & $\beta$ & $t$ & $p$ & İkili $r$ & Klsmi $r$ \\
\hline Sabit & 74.975 & 2.678 & - & 27.996 & $.000 *$ & - & - \\
\hline Öz-yeterlik & .307 & .042 & .511 & 7.263 & $.000 *$ & .511 & .511 \\
\hline $\mathrm{R}=0.511, \quad \mathrm{R}^{2}=0.261$ & $F_{(1,149)}=$ & 386 & & & & & \\
\hline
\end{tabular}

Öğrencilerin geometriye yönelik öz-yeterlik inançları, geometri problemi kurma becerileri ile orta düzeyde ve anlamlı bir ilișki vermektedir $\left(\mathrm{R}=0.511, \mathrm{R}^{2}=0.261, p<.05\right)$. Ayrıca geometri problemi kurma becerilerine ilişkin toplam varyansın \%26'sının öğrencilerin geometriye yönelik öz-yeterlik inançları ile açıklandığı bulunmuştur. Regresyon katsayılarının anlamlılığına ilişkin t-testi sonuçları incelendiğinde ise, öğrencilerin geometriye yönelik öz-yeterlik inançlarının, geometri problemi kurma becerilerinin anlamlı bir yordayıcısı olduğu görülmüştür. Ayrıca bu bulgu, geometriye yönelik öz-yeterlik inançları ile geometri problemi kurmanın ilişkili olduğunu göstermektedir.

\section{Tartışma ve Sonuç}

Bu çalışmada, sekizinci sınıfta öğrenim gören öğrencilerin geometri problemi kurma becerileri ile geometriye yönelik öz-yeterlik inançlarının ilişkisi araştırılmıştır. Ayrıca öğrencilerin geometri problemi kurma becerileri cinsiyet, aile eğitim durumları ve başarı değişkenleri açısından incelenmiştir.

Öğrencilerin geometri problemi kurma becerileri cinsiyete göre anlamlı farklılık göstermemektedir. Bunun yanında farklı problem kurma durumlarına göre de anlamlı bir farklılık bulunmamaktadır. Literatürde farklı sınıf düzeyleri ile yapılan çalışmalar da bu sonuçla uyuşmaktadır (Cankoy \& Darbaz, 2010; Salman, 2012). Bu sonucun dişında erkeklerin (Akkan ve diğerleri, 2009) ve kadınların (Muyo, 2015; Semizoğlu, 2013) 
daha başarılı olduğunu belirten araştırmalar olduğu da görülmüştür. Bu konuda Özgen ve diğerleri (2017) problem kurma becerilerinin cinsiyet değişkeni açısından okulun konumuna, sinifların sosyo-ekonomik durumuna ya da diğer faktörlere göre değişebileceğini belirtmişlerdir. Bunar (2011), altıncı sınıf öğrencilerinin kümeler, kesirler ve dört işlem konularında problem kurma ve problem çözme becerilerini incelemiştir. Araştırmada kız öğrenciler dört işlem ve kesirler (şekilsiz) ile ilgili problem kurmada erkek öğrencilere göre daha başarılı olurken, kümeler ve kesirler (şekilli) konusunda problem kurmada öğrenciler arasında anlamlı bir fark bulunamamıştır. Akkan ve diğerleri (2009), ortaokul öğrencilerinin denklem oluşturma ve problem kurma ile ilgili yeterliliklerde, erkek öğrencilerin az da olsa kız öğrencilere göre daha yeterli olduklarını bulmuşlardır. Çalışmanın sonuçları literatür ile karşılaştırıldığında bu konuda çeşitli sonuçların bulunduğu görülmektedir.

Sekizinci sınıf öğrencilerinin geometri problemi kurma becerilerinin anne eğitim durumlarına göre anlamlı farklılık göstermesi ortaya çıkan bir başka sonuçtur. Ayrıca öğrencilerin yapılandırılmış problem kurma durumlarında elde ettiği puanların anne eğitim durumlarına göre anlamlı bir farklılık gösterdiği bulunmuştur. Bunun sonucunda, anne eğitim düzeyi yüksek öğrencilerin geometri problemi kurma etkinliklerinde daha başarılı olduğu söylenebilir. Ancak; öğrencilerin diğer problem kurma durumlarında elde ettiği puanlarda böyle bir sonuç bulunmamaktadır. Analiz sonuçlarına bakıldığında, sekizinci sınıf öğrencilerinin geometri problemi kurma becerileri baba eğitim durumları açısından da anlamlı farklılık göstermektedir. Aynı sonuç öğrencilerin yarıyapılandırılmış problem kurma durumlarında elde ettikleri puanlarda da bulunmuştur. $\mathrm{Bu}$ sonuç ile baba eğitim düzeyi arttıkça öğrencilerin geometri problemi kurma etkinliklerinde daha başarılı olduğu söylenebilir. Buna karşılık, öğrencilerin serbest ve yapılandırılmış problem kurma durumlarındaki puanları baba eğitim durumları açısından anlamlı bir farklılık göstermemektedir. Literatürde problem kurma ve annebaba eğitim durumları arasındaki ilişkiyle ilgili çalışmaya rastlanmasa da ailenin eğitim durumunun öğrencilerin başarıları ile ilişki olduğunu ortaya koyan çalışmalar görülmektedir. Özkan (2010), aile eğitim durumunun geometri başarısı üzerinde etkili olduğunu vurgulamıştır. Keçeli-Kaysılı (2008) ise aile katılımının öğrencilerin akademik becerilerini artırdığını belirtmiştir. Literatür ve araştırmanın sonuçları düşünüldüğünde, aile eğitim durumunun öğrencilerin problem kurma becerileri üzerinde önemli bir etken olduğundan bahsedilebilir.

Araştırma başarı değişkeni açısından incelendiğinde, öğrencilerin başarılarının geometri problemi kurma becerileri üzerinde bir farklılık oluşturduğu sonucuna ulaşılmıştır. Ayrıca problem kurma durumları açısından da öğrenci başarısının önemli bir etken olduğu söylenebilir. Buradan yüksek başarıya sahip öğrencilerin geometri problemi kurma etkinliklerinde daha başarılı olduğu sonucuna ulaşılmıştır. Alanyazında bulunan çalışmalar da bu sonucu desteklemektedir (Dickerson, 1999; Özgen ve diğerleri, 2017; Şengül-Akdemir \& Türnüklü, 2017; Yuan \& Sriraman, 2011).

Özgen ve diğerleri (2017), problem kurma etkinliklerinin matematik dersinin dışında başka derslere de olumlu etkisi olabileceğini ifade etmişlerdir. Dolayısı ile öğrencilerin problem kurma etkinlikleri ile uğraşmaları başarılarını tetikleyici bir unsur olabilir. Nitekim problem kurma yaklaşımıyla yapılan bir dersin öğrencilerin akademik başarılarında olumlu etkileri olacağı belirtilmektedir (Akay \& Boz, 2009). 
Şengül-Akdemir ve Türnüklü (2017), öğrencilerin genellikle matematik başarı düzeyleri doğrultusunda problemler kurduklarını belirtmişlerdir. Başarılı öğrenciler daha fazla problem kurarken, başarı düzeyi düşük öğrenciler daha az problem kurmaktadır. Burada, problem kurma etkinliklerinin öğrencilerin matematik kavramlarını anlamada önemli rol oynaması da (Chang, Wu, Weng, \& Sung, 2012) matematik başarısı ile ilişkilendirilebilir. Bir başka çalışmada Ekici (2016), öğrencilerin akademik yeterlilik düzeyinin öğrencilerin kurdukları problemleri etkilediğini ifade etmiştir. Yuan ve Sriraman (2011) ise, öğrencilerin problem kurma becerilerinin matematik bilgisinden etkilenebildiğini belirtmişlerdir.

Bu sonuçlar dikkate alındığında, başarılı öğrencilerin problem kurmada daha iyi sonuçlar aldığı söylenebilir. Aynı zamanda öğrencilerin başarıları arttıkça problem kurma başarıları da aynı şekilde artmaktadır. Öğrencilerin başarı düzeyleri dikkate alınarak problem kurma etkinlikleri yapılmalıdır. Problem kurma türlerinin de başarı ile ilişkili olduğu düşünüldüğünde her durum ile ilgili farklı etkinlikler uygulanabilir.

$\mathrm{Bu}$ araştırmada, öğrencilerin geometriye yönelik öz-yeterlik inançlarının, geometri problemi kurma becerilerini yordadığı sonucuna ulaşılmıştır. Bir başka ifadeyle, öğrencilerin geometriye yönelik öz-yeterlik inançları ile geometri problemi kurma becerilerinin ilişkili olduğu bulunmuştur. Bu sonuca benzer olarak Çontay (2012), sekizinci sınıf öğrencilerinin geometrik cisimler konusunda yazma etkinliklerinin, öğrencilerin geometriye yönelik öz-yeterlik düzeyleri üzerinde olumlu etkiye sahip olabileceği sonucuna ulaşmıştır. Öz-yeterlikle ilgili bir diğer çalışmada Akay ve Boz (2010), problem kurma odaklı bir dersin öğretmen adaylarının matematik öz-yeterlik inançlarına olumlu etkisi olduğunu bulmuşlardır.

Literatürde öz-yeterliğin, problem kurma ile ilişkisini inceleyen pek fazla çalışmaya rastlanmasa da problem çözme ile ilişkisini inceleyen çalışmalar bulunmaktadır (Chen, 2005; Hoffman \& Schraw, 2009; Pajares \& Kranzler, 1995; Pajares \& Miller, 1994). Problem çözme üzerine yapılan araştırmalardan birinde Hoffman ve Schraw (2009), öz-yeterliğin problem çözme performansını artırdığını belirtmektedirler. Chen (2005), öz-yeterliğin problem çözme becerisini olumlu yönde etkilediğini bulmuştur.

Bir başka çalışmada Nicolaou ve Philippou (2007), matematikte öz-yeterlik inançlarının problem kurma becerileri üzerinde güçlü bir etkisi olduğundan bahsetmektedirler. Literatürde yer alan tüm bu görüşler çerçevesinde öz-yeterlik inançlarının problem çözme ve problem kurma üzerinde bir etkisi olduğu söylenebilir. $\mathrm{Bu}$ araştırmanın sonuçları düşünüldüğünde, öğrencilere geometri problemi kurma firsatları tanındığında veya öğrenciler geometri problemi kurmaları konusunda teşvik edildiklerinde bu durumdan geometri öz-yeterlik inançları da olumlu etkilenecektir.

\section{Öneriler}

- Yapılan bu araştırma ile sekizinci sınıf öğrencilerinin geometri öz-yeterlik inançları ile geometri problemi kurma becerilerinin arasında bir ilişki olduğu bulunmuştur. $\mathrm{Bu}$ sonuçtan hareketle, sınıf ortamında öğrencilerin geometri konusunda kendilerine güvenmeleri için geometri problemi kurma firsatları tanınması önerilmektedir. 
- $\mathrm{Bu}$ araştırmada öğrencilerin başarılarıyla geometri problemi kurma becerilerinin ilişkili olduğu sonucuna varılmıştır. Buna yönelik olarak öğretmenlerin, öğrencilerin başarı seviyelerine yönelik farklı durumları içeren geometri problemi kurma etkinlikleri tasarlamaları önerilmektedir.

- Anne-baba eğitim durumunun öğrencilerin problem kurma becerileri ile ilişkili olduğu bulunmuştur. Bu açıdan okul-aile işbirliği sağlanabilir.

- $\mathrm{Bu}$ araştırmada sekizinci sınıf öğrencilerinin üçgenler ve eşlik-benzerlik alt öğrenme alanına yönelik olarak kurdukları problemler incelenmiştir. Ortaokul öğrencilerinin geometrinin diğer alt öğrenme alanları ile ilgili problem kurma becerileri araştırılabilir.

- Araştırmada geometri problemi kurma becerileri geometri öz-yeterlik inançları açısından ele alınmıştır. Geometri problemi kurma becerileri ile tutum ve kaygı gibi diğer duyuşsal beceriler arasında ilişki olup olmadığı araştırılabilir. 


\section{Summary}

Purpose and Significance: Singer, Ellerton, and Cai (2015) stated that problem posing is an important part of school mathematics. Despite the fact that there are many studies in problem posing conducted with middle school students (Akkan, Çakıroğlu, \& Güven, 2009; Bonotto, 2013; Bunar, 2011; Cai, 1998; Stoyanova, 2005; Turhan \& Güven, 2014) about numbers and operations or algebra learning domains, the lack of studies on the geometry learning domain draws attention. Considering the view that problem posing is important in mathematics education, the examination of problem posing in geometry is also considered as a matter to be investigated.

In the literature, there are a limited number of studies investigating the relationship between problem posing and self-efficacy beliefs. For this reason, it is thought that it is necessary to investigate geometry problem posing skills in terms of geometry selfefficacy beliefs of middle school students. Therefore, the aim of the research is to investigate the relationship between geometry problem posing skills and geometry selfefficacy beliefs of eighth grade students in different problem posing situations. In addition, geometry problem posing skills of the students has been researched in terms of gender, parental education status, general academic success and mathematics course success.

Methods: The research is a quantitative study designed in the survey model to investigate geometry problem posing skills of eighth grade students in terms of some variables. The research group was composed of 151 students who were studying at the eighth grade. In this study, data were collected with "Geometry Problem Posing Test", "Self-Efficacy Scale Toward Geometry ", and "Personal Information Form".

The Geometry Problem Posing Test was prepared about the sub-learning domains of triangles and congruent-similarity in the domain of geometry and measurement learning in the eighth grade teaching program. In the test consisting of 6 open-ended questions, there are questions including Pythagorean relation and congruent-similarity concepts for free problem posing situations. For semi-structured problem posing situations, some problems including angle-edge relation and triangle inequality context have been asked to the participants. For structured problem posing situations, there are problems involving basic similarity theorem and auxiliary elements of triangle. In order to ensure the validity and reliability of the test, the opinions of two expert academicians in mathematics education were consulted before and after the pilot application.

The "Self-Efficacy Scale toward Geometry" developed by Cantürk-Günhan and Başer (2007) was used to determine students' self-efficacy beliefs towards geometry. There are 25 items on the scale that measure the self-efficacy beliefs towards geometry of the middle school students in various dimensions. The scale consists of three subdimensions about positive self-efficacy beliefs, use of geometrical knowledge, and negative self-efficacy beliefs. The general Cronbach Alpha coefficient of scale was found to be .90 in both the original study and this study.

An analytical rubric, developed by Özgen, Aydın, Geçici, and Bayram (2017), was used for the analysis of the problems that students posed. In this rubric, there are seven evaluation criteria. To ensure the reliability of the study, interrater reliability method 
was applied. The percentage of concordance between coders was found as $78 \%$. In the analysis of the data, t-test, one way variance analysis and regression analysis were used.

Results: This study revealed that there was no significant difference in geometry problem posing skills of eighth grade students according to the gender variable. Furthermore, the skills of the students in different problem posing situations did not show any statistically significant difference according to gender. Another result was that the geometry problem posing skills of eighth grade students had a significant difference in terms of their mothers' educational status. Also, there was a significant difference the students' scores on structured problem posing situations in terms of their mothers' educational status. According to the results of the analysis, the eighth grade students had a significant difference in their geometry problem posing skills in terms of their fathers' educational status, as well. Besides, there was a significant difference the students' scores on semi-structured problem posing situations in terms of their fathers' educational status.

To sum up briefly, the students' both general academic success and mathematics course success have a statistically significant difference on the geometry problem posing test scores. In addition, statistically significant differences were found in both academic success and mathematics course success according to each of problem posing situations. Furthermore, it was concluded that eighth grade students' self-efficacy beliefs toward geometry were a significant predictor of geometry problem posing skills. In other words, there is a moderate correlation and meaningful relationship between students' self-efficacy beliefs towards geometry and their geometry problem posing skills.

Discussion and Conclusions: It can be said that successful students are better than unsuccessful students in problem posing. At the same time, as student success increases, problem posing success is also increasing. Problem posing activities should be carried out by considering the success levels of students. Different activities can be applied to each situation when it is considered that the types of different problem posing are also related to success. 


\section{Kaynakça}

Akay, H., \& Boz, N. (2009). The effect of problem posing oriented calculus-II instruction on academic success. Research in Mathematical Education, 13(2), 7590.

Akay, H., \& Boz, N. (2010). The effect of problem posing oriented analyses-II course on the attitudes toward mathematics and mathematics self-efficacy of elementary prospective mathematics teachers. Australian Journal of Teacher Education, 35(1), $59-75$.

Akkan, Y., Çakıroğlu, Ü., \& Güven, B. (2009). İlköğretim 6. ve 7. sınıf öğrencilerinin denklem oluşturma ve problem kurma yeterlilikleri. Mehmet Akif Ersoy Üniversitesi Eğitim Fakültesi Dergisi, 9(17), 41-55.

Altıntaş, Y. D., \& Tanrıseven, I. (2017). Sınıf öğretmenlerinin problem kurma özyeterlik inanç düzeylerinin belirlenmesi. Route Educational and Social Science Journal, 4(2), 33-42.

Altun, M. (2014). Matematik ögretimi (10. baskı). Bursa: Aktüel.

Arıkan, E. E., \& Unal, H. (2015). An investigation of eighth grade students' problem posing skills (Turkey sample). International Journal of Research in Education and Science, 1(1), 23-30.

Baki, A. (2008). Kuramdan uygulamaya matematik eğitimi (4. baskı). Ankara: Harf Eğitim Yayıncılığı.

Bıkmaz, F. (2014). Öz yeterlik inançları. (Editörler: Y. Kuzgun \& D. Deryakulu). Eğitimde bireysel farklılıklar. Nobel yayın dağıtım (3. baskı): Ankara, 291-316.

Bonotto, C. (2013). Artifacts as sources for problem-posing activities. Educational Studies in Mathematics, 83(1), 37-55.

Brown, S. I., \& Walter, M. I. (2005). The art of problem posing ( $3^{\text {rd }}$ ed.). New York: Psychology Press.

Bunar, N. (2011). Altıncı sinıf ögrencilerinin kümeler, kesirler ve dört işlem konularında problem kurma ve çözme becerileri (Yayımlanmamış Yüksek Lisans Tezi). Afyon Kocatepe Üniversitesi, Sosyal Bilimler Enstitüsü, Afyonkarahisar.

Cai, J. (1998). An investigation of US and Chinese students' mathematical problem posing and problem solving. Mathematics Education Research Journal, 10(1), 3750 .

Cankoy, O., \& Darbaz, S. (2010). Problem kurma temelli problem çözme öğretiminin problemi anlama başarısına etkisi. Hacettepe Üniversitesi Eğitim Fakültesi Dergisi, $38,11-24$.

Cantürk-Günhan, B., \& Başer, N. (2007). Geometriye yönelik öz-yeterlik ölçeğinin geliştirilmesi. Hacettepe Üniversitesi Ĕ̆itim Fakültesi Dergisi, 33, 68-76.

Chang, K. E., Wu, L. J., Weng, S. E., \& Sung, Y. T. (2012). Embedding game-based problem-solving phase into problem-posing system for mathematics learning. Computers \& Education, 58(2), 775-786.

Chen, S. (2005). The relationship between mathematical beliefs and performance: a study of students and their teachers in Beijing and New York (Doctoral Dissertation). Columbia University, New York. 
Christou, C., Mousoulides, N., Pittalis, M., Pitta-Pantazi, D., \& Sriraman, B. (2005). An empirical taxonomy of problem posing processes. ZDM, 37(3), 149-158.

Chua, P. H., \& Wong, K. Y. (2012). Characteristics of problem posing of grade 9 students on geometric tasks. In J. Dindyal, L. P. Cheng \& S. F. Ng (Eds.), Mathematics education: Expanding horizons (Proceedings of the 35th annual conference of the Mathematics Education Research Group of Australasia). Singapore: MERGA.

Cifarelli, V. V., \& Sevim, V. (2015). Problem posing as reformulation and sensemaking within problem solving. In F. M. Singer, N. Ellerton, \& J. Cai (Eds.), Mathematical problem posing: From research to effective practice (pp. 177-194). New York (NY): Springer.

Creswell, J.W. (2014). Research design: qualitative, quantitative and mixed methods approaches $\left(4^{\text {th }}\right.$ edition). Thousand Oaks: Sage.

Çarkçı, İ. (2016). İlkokul 4. sınıf öğrencilerinin farklı problem kurma durumlarına yönelik ortaya koydukları problemlerin incelenmesi (Yayımlanmamış Yüksek Lisans Tezi). Gazi Üniversitesi, Eğitim Bilimleri Enstitüsü, Ankara.

Çelik, A., \& Yetkin-Özdemir, E. (2011). İlköğretim öğrencilerinin orantısal akı1 yürütme becerileri ile oran-orantı problemi kurma becerileri arasındaki ilişki. Pamukkale Üniversitesi Eğitim Fakültesi Dergisi, 30(1), 1-11.

Çontay, E. G. (2012). Geometrik cisimlerin yüzey alanları ve hacimleri konusunda yazma etkinliklerinin 8. sını ögrencilerinin başarılarına ve geometriye yönelik özyeterliklerine etkisi (Yayımlanmamış Yüksek Lisans Tezi). Pamukkale Üniversitesi Fen Bilimleri Enstitüsü, Denizli.

Deringöl, Y. (2018). Sınıf öğretmeni adaylarının matematik problemi çözmeye yönelik inançları ile problem kurma özyeterlik inançlarının incelenmesi. Türk Bilgisayar ve Matematik Ĕ̈itimi Dergisi, 9(1), 31-53.

Dickerson, V. M. (1999). The impact of problem posing instruction on the mathematical problem solving achievement of seventh graders (Unpublished Doctoral Dissertation). University of Emory, Atlanta.

Ekici, D. (2016). Ortaokul ögrencilerinin problem kurma stratejilerinin belirlenmesi (Yayımlanmamış Yüksek Lisans Tezi). Dokuz Eylül Üniversitesi, Eğitim Bilimleri Enstitüsü, İzmir.

George, D., \& Mallery, M. (2010). Spss for windows step by step: A simple guide and reference (17.0 update). Boston: Pearson.

Gonzales, N. A. (1994). Problem posing: A neglected component in mathematics courses for prospective elementary and middle school teachers. School Science and Mathematics, 94(2), 78-84.

Hoffman, B., \& Schraw, G. (2009). The influence of self-efficacy and working memory capacity on problem-solving efficiency. Learning and Individual Differences, 19(1), 91-100.

Kaba, Y., Boğazlıyan, D., \& Daymaz, B. (2016). Ortaokul öğrencilerinin geometriye yönelik tutumları ve öz-yeterlikleri. The Journal of Academic Social Science Studies, 52(Winter I), 335-350. 
Kar, T. (2016). Prospective middle school mathematics teachers' knowledge of linear graphs in context of problem-posing. International Electronic Journal of Elementary Education, 8(4), 643-658.

Karasar, N. (2008). Bilimsel araştırma yöntemi (18. baskı). Ankara: Nobel Yayın Dağıtım.

Keçeli-Kaysılı, B. (2008). Akademik başarının arttırılmasında aile katılımı. Ankara Üniversitesi Eğitim Bilimleri Fakültesi Özel Ĕ̈itim Dergisi, 9(1), 69-83.

Kılıç, Ç. (2013). Sınıf öğretmeni adaylarının farklı problem kurma durumlarında sergilemiş oldukları performansın belirlenmesi. Kuram ve Uygulamada Eğitim Bilimleri, 13(2), 1195-1211.

Kılıç, Ç., \& İncikabı, L. (2013). Öğretmenlerin problem kurma ile ilgili öz-yeterlik inançlarının belirlenmesine yönelik ölçek geliştirme çalışması. Dumlupınar Üniversitesi Sosyal Bilimler Dergisi, 35, 223-234.

Kırnap-Dönmez, M. S. (2014). İlköğretim matematik öğretmen adaylarının problem kurma becerilerinin incelenmesi (Yayımlanmamış Yüksek Lisans Tezi). Erciyes Üniversitesi, Eğitim Bilimleri Enstitüsü, Kayseri.

Kilpatrick, J. (1987). Problem formulating: Where do good problems come from? In A. H. Schoenfeld (Ed.), Cognitive science and mathematics education (pp. 123-147). New Jersey, Lawrence Erlbaum Associates, Inc.

Lavy, I., \& Bershadsky, I. (2003). Problem posing via "what if not?" strategy in solid geometry-A case study. The Journal of Mathematical Behavior, 22(4), 369-387.

Milli Eğitim Bakanlığı [MEB]. (2009). İlköğretim matematik dersi ögretim programı ve kılavuzu. Ankara: MEB Basımevi.

Milli Eğitim Bakanlığı [MEB]. (2013). Ortaokul matematik dersi (5, 6, 7 ve 8. Sinıflar) ögretim programı. Ankara: MEB Basımevi.

Milli Eğitim Bakanlığı [MEB]. (2018). Matematik Dersi Öğretim Programı (İlkokul ve Ortaokul 1, 2, 3, 4, 5, 6, 7 ve 8. Sinıflar). Ankara: MEB Basımevi.

Miles, M. B., \& Huberman, A. M. (1994). An expanded source book: Qualitative data analysis. London: Sage Publications.

Muyo, M. (2015). Prizren eğitim fakültesi öğrencilerinin matematik okuryazarlı̆̆ problemlerini çözme becerilerinin geliştirilmesi (Yayımlanmamış Doktora Tezi). Balıkesir Üniversitesi, Fen Bilimleri Enstitüsü, Balıkesir.

National Council of Teachers of Mathematics [NTCM]. (2000). Principles and standard for school mathematics. Reston, VA: National Council of Teachers of Mathematics.

Ngah, N., Ismail, Z., Tasir, Z., \& Mohamad Said, M. N. H. (2016). Students' ability in free, semi-structured and structured problem posing situations. Advanced Science Letters, 22(12), 4205-4208.

Nicolaou, A.A., \& Philippou, G. N. (2007). Efficacy beliefs, problem posing, and mathematics achievements. In D. Pitta-Pantazi, \& G. Phillippou (Eds.), Proceedings of the $V$ Congress of the European Society for Research in Mathematics Education (pp. 308-317). Larnaca, Cyprus: Department of Education, University of Cyprus. 
Olkun, S., \& Toluk-Uçar, Z. (2014). İlköğretimde etkinlik temelli matematik öğretimi (6. bask1). Ankara: Eğiten Kitap.

Özgen, K., \& Bayram, B. (2018). Problem kurma öz yeterlik ölçeğinin geliştirilmesi. 27. Uluslararası Eğitim Bilimleri Kongresi'nde sunulan bildiri, Antalya. http://icesuebk.org/? $=0$ adresinden 17.04.2018 tarihinde edinilmiştir.

Özgen, K., \& Bindak, R. (2011). Lise öğrencilerinin matematik okuryazarlığına yönelik öz-yeterlik inançlarının belirlenmesi. Kuram ve Uygulamada Eğitim Bilimleri, 11(2), 1073-1089.

Özgen, K., Aydın, M., Geçici, M. E., \& Bayram, B. (2017). Sekizinci sınıf öğrencilerinin problem kurma becerilerinin bazı değişkenler açısından incelenmesi. Türk Bilgisayar ve Matematik Ĕ̈itimi Dergisi, 8(2), 218-243.

Özkan, E. (2010). Geometri öz-yeterliği, cinsiyet, sinıf seviyesi, anne-baba eğitim durumu ve geometri başarısı arasındaki ilişkiler (Yayımlanmamış Yüksek Lisans Tezi). Abant İzzet Baysal Üniversitesi, Sosyal Bilimler Enstitüsü, Bolu.

Pajares, F. (1996). Self-efficacy beliefs in academic settings. Review of Educational Research, 66, 543-578.

Pajares, F., \& Kranzler, J. (1995). Self-efficacy beliefs and general mental ability in mathematical problem-solving. Contemporary Educational Psychology, 20(4), 426443.

Pajares, F., \& Miller, M. D. (1994). Role of self-efficacy and self-concept beliefs in mathematical problem solving: A path analysis. Journal of Educational Psychology, 86(2), 193-203.

Polya, G. (1973). How to solve it: A new aspect of mathematical method. New Jersey: Princeton University Press.

Salman, E. (2012). İlköğretim matematik öğretiminde problem kurma çalışmalarının ögrencilerin problem çözme başarısına ve tutumlarına etkisi (Yayımlanmamış Yüksek Lisans Tezi). Erzincan Üniversitesi, Fen Bilimleri Enstitüsü, Erzincan.

Semizoğlu, R. (2013). İlköğretim 5. sinıf ögrencilerinin okuduğunu anlama ve görsel okuma düzeyi ile problem kurma becerileri arasındaki ilişkinin incelenmesi (Yayımlanmamış Yüksek Lisans Tezi). Gazi Üniversitesi, Eğitim Bilimleri Enstitüsü, Ankara.

Silber, S., \& Cai, J. (2017). Pre-service teachers' free and structured mathematical problem posing. International Journal of Mathematical Education in Science and Technology, 48(2), 163-184.

Silver, E. A. (1994). On mathematical problem posing. For the Learning of Mathematics, 14(1), 19-28.

Silver, E. A., \& Cai, J. (1996). An analysis of arithmetic problem posing by middle school. Journal For Research in Mathematics Education, 27, 521-539.

Singer, F. M., Ellerton, N. F., \& Cai, J. (Eds.). (2015). Mathematical problem posing: From research to effective practice. New York (NY): Springer.

Singer, F. M., Voica, C., \& Pelczer, I. (2017). Cognitive styles in posing geometry problems: Implications for assessment of mathematical creativity. ZDM Mathematics Education, 49(1), 37-52. https://doi.org/10.1007/s11858-016-0820-x 
Stoyanova, E. (1997). Extending and exploring students' problem solving via problem posing: A study of years 8 and 9 students involved in mathematics challenge and enrichment stages of Euler enrichment program for young Australians (Unpublished doctoral dissertation). Edith Cowan University, Perth, Australia.

Stoyanova, E. (2005). Problem-posing strategies used by years 8 and 9 students. Australian Mathematics Teacher, 61(3), 6-11.

Stoyanova, E., \& Ellerton, N. F. (1996). A framework for research into students' problem posing in school mathematics. In P. Clarkson (Ed.), Technology in mathematics education (pp.518-525). Melbourne: Mathematics Education Research Group of Australasia.

Şengül-Akdemir, T., \& Türnüklü, E. (2017). Ortaokul 6. sınıf öğrencilerinin açılar ile ilgili problem kurma süreçlerinin incelenmesi. International Journal of New Trends in Arts, Sports \& Science Education, 6(2), 17-39.

Turhan, B., \& Güven, M. (2014). Problem kurma yaklaşımıyla gerçekleştirilen matematik öğretiminin problem çözme başarısı, problem kurma becerisi ve matematiğe yönelik görüşlere etkisi. Çukurova Üniversitesi Eğitim Fakültesi Dergisi, 43(2), 217-234.

Türnüklü, E., Ergin, A. S., \& Aydoğdu, M. Z. (2017). 8. sınıf öğrencilerinin üçgenler konusunda problem kurma çalışmalarının incelenmesi. Bayburt Eğitim Fakültesi Dergisi, 12(24), 467-486.

Ünlü, M. (2014). Geometri başarısını etkileyen faktörler: Bir yapısal eşitlik modellemesi (Yayımlanmamış Doktora Tezi). Necmettin Erbakan Üniversitesi, Eğitim Bilimleri Enstitüsü, Konya.

Ünlü, M., \& Aktaş, G. S. (2016). İlköğretim matematik öğretmen adaylarının problem kurma özyeterlik ve problem çözmeye yönelik inançları. Abant İzzet Baysal Üniversitesi Eğitim Fakültesi Dergisi, 16(4), 2040-2059.

Ünlü, M., \& Ertekin, E. (2017). A structural equation model for factors affecting eighth graders' geometry achievement. Educational Sciences: Theory \& Practice, 17, 1815-1846. http://dx.doi.org/10.12738/estp.2017.5.0545

Walter, M. (1980). Frame geometry: An example in posing and solving problems. The Arithmetic Teacher, 28(2), 16-18.

Yuan, X., \& Sriraman, B. (2011). An exploratory study of relationships between students' creativity and mathematical problem-posing abilities. In B. Sriraman \& K. Lee (Eds.), The elements of creativity and giftedness in mathematics (pp. 5-28). Rotterdam: Sense Publishers.

Zimmerman, B. J. (1995). Self-efficacy and educational development. In A. Bandura, (Ed.), Self-efficacy in changing socities (pp. 202-231). New York: Cambridge University Press. 
Ek-1

GEOMETRİ PROBLEMİ KURMA TESTİ-1

Aşağıdaki yönergeleri uygulayıp sizden istenen durumlarn kullanarak birer problem yazinız.

Problem kurarken dikkat etmeniz gerekenler!

- Yazdığmız problemler açık ve anlaşılır olmalı,

- Problemler, verilenler ve istenenlerden olușmal,

- Açık bir soru cümlesi içermelidir.

- Olușturduğunuz problemlerin çözümlerini de açlk bir șekilde yazmanız gerekmektedir.

- Yazdığınız problemler öğretmenlerinizden veya bașka kaynaklardan esinlendiğiniz problemler olabilir.

1) 'Misır' da Nil Nehri'nde bahar aylarında meydana gelen taşkınlar nedeniyle arazi sınırları sürekli değişiyor bu nedenle de arazilerin sınırlarının siklıkla yeniden belirlenmesi gerekiyordu. Bu amaçla dik kenar uzunlukları bilinen dik üçgenlerin hipotenüs uzunluğunu veren bir bağıntı kullanılıyordu. Bu bağıntının ilk kez ne zaman ve kimin tarafindan kullanıldığ 1 tam olarak bilinmemekle beraber, bağıntının ilk kez Yunanlı matematikçi Pisagor (Pythagoras) tarafindan ispat edildiği düşünülmektedir."

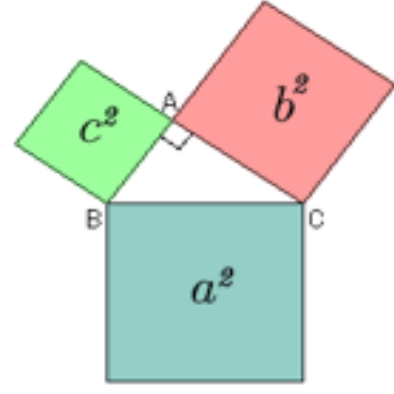

$$
c^{2}+b^{2}=a^{2}
$$

Sizde Pisagor bağıntısımı iceren bir problem kurunuz ve cözünüz.

(Serbest Problem Kurma Durumu)

2)

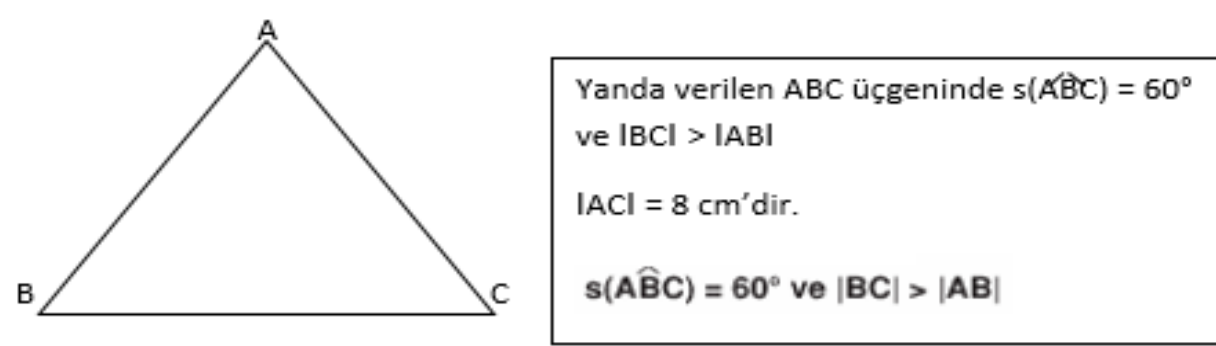

Verilen bilgileri değistirmeden, bu bilgileri kullanarak bir problem kurup cözünüz.

(Yar1-Yapilandırilmış Problem Kurma Durumu)

3)

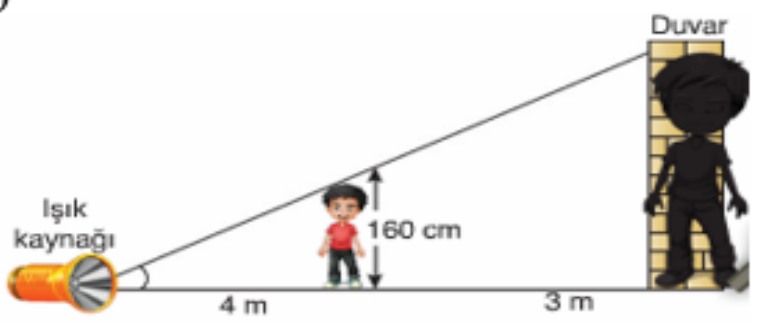

Şekilde, Kağan'ın gölgesinin duvardaki görüntūsū ve ışık kaynağı ile Kağan ve duvar arasındaki uzaklık verilmiştir.

Buna göre, Kağan'ın gölgesinin boyu kaç $\mathrm{cm}^{\prime} \mathrm{dir}$ ?

Yukarida verilen probleme veya problemdeki iliskive benzer baska bir problem kurunuz ve cözünüz

(Yapılandırılmış Problem Kurma Durumu) 


\section{GEOMETRI PROBLEMI KURMA TESTI-2}

Așağıdaki yönergeleri uygulayıp sizden istenen durumları kullanarak birer problem yazınız.

Problem kurarken dikkat etmeniz gerekenler!

- Yazdığınız problemler açık ve anlaşılır olmal,,

- Problemler, verilenler ve istenenlerden olușmal,

- Açlk bir soru cümlesi içermelidir.

- Olușturduğunuz problemlerin çözümlerini de açı bir şekilde yazmanız gerekmektedir.

- Yazdığınız problemler öğretmenlerinizden veya bașka kaynaklardan esinlendiğiniz problemler olabilir.

1) "Karşı1ıklı kenar uzunlukları eşit ve açı ölçüleri eş olan çokgenlere eş çokgenler denir."

"Aç1ların ölçüleri eşit karşıllklı kenar uzunlukları orantılı olan çokgenlere benzer çokgenler denir."

Yukarıda eşlik ve benzerlik kavramlarının tanımları verilmiștir. Sizde ücgenlerde eslik veya benzerlik ile ilgili problem kurup cözümünü yapmız.

(Serbest Problem Kurma Durumu)

2)

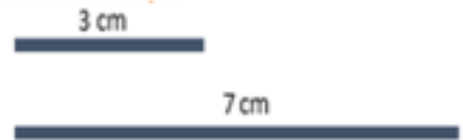

Elinde $3 \mathrm{~cm}$ ve $7 \mathrm{~cm}$ uzunluğunda iki tahta çubuk bulunan Onur bir tane daha tahta çubuk kullanarak üçgen bir çerçeve yapmak istiyor.

Yukarnda verilen bilgileri kullanarak bir problem kurunuz ve cözünüz. (Yarı-Yapilandırılmış Problem Kurma Durumu)

3)

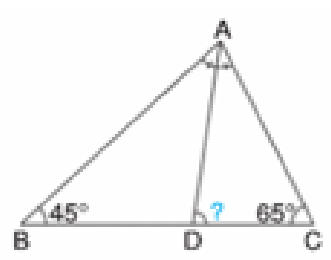

Şekildeki ABC äģgeninde [AD] açıortaydir.

Verilenlere gốre ADC açısının ölçūsū kaç derecedir?
Yanda verilen problemdeki gibi üçgenin yardımcı elemanlarından (AçırtayKenarortay-Yükseklik) oluşan bir problem kurunuz ve çözünüz. (Yapılandırılmış Problem Kurma Durumu) 